\title{
Microbial activities and physicochemical properties of coniferous forest soils in two forest areas (arid and semi-arid) of western Algeria
}

\author{
Actividades microbianas y propiedades fisicoquímicas de los suelos forestales de coníferas \\ en dos zonas forestales (áridas y semiáridas) del oeste de Argelia
}

\author{
Zouidi Mohamed a,b*, Borsali Amine Habib a,b, Allam Ayoub a, Gros Raphael c \\ *Corresponding Author: ${ }^{*}$ University of Saïda, Faculty of Science, Department of Biology, Algeria, bio.zouidi1991@hotmail.com \\ b University of Saïda, Laboratory "Water resources and environment”, Algeria, phone: +213658444013. \\ 'St. Jerome, Aix-Marseille University, Faculty of Sciences and Techniques, Institut Mediterranean Biodiversity and Ecology, \\ UMR CNRS IRD 7263, Team vulnerability of microbial systems, 452 Service of,13397 Marseille cedex 20, France.
}

\section{SUMMARY}

The Algerian forest, the last bulwark against desertification coming from Sahel, is particularly vulnerable to global change and must be protected from deforestation, which is constantly advancing. Aleppo pine, which covers 880,000 ha, is the predominant species of forests in semi-arid and arid regions. The soils of these regions are generally fragile and vulnerable due to climatic aridity; their degradation today has accentuated the phenomenon of desertification. The objective of this work was to compare the physicochemical and microbiological characteristics of the coniferous forest soils of the semi-arid and arid zones of the Algerian west. In addition to characterization of climates, 16 physical, chemical and microbiological properties were analyzed on soils collected from forest areas characteristic of the two zones: Jebel Sid Ahmed Zeggai forest massif (Saida province) located in the semi-arid zone and the forest massif of jebel Antar (Naama province) located in the arid zone. Our results showed very different soil qualities between the two zones: moisture content, water retention capacity, permeability, porosity and organic carbon content, total nitrogen and organic matter are higher in the semi-arid zone compared with the arid zone, which is characterized by the large presence of total limestone. Biomass and microbial basal respiration are higher in the semi-arid zone. Our results are discussed with regard to the vulnerability of soils to the respective climate of each of the zones and agro-silvo practices potentially involved in the degradation of these soils.

Key words: soil quality, Aleppo pine, degradation, drought, vulnerability.

\section{RESUMEN}

El bosque argelino, el último baluarte contra la desertificación procedente del Sahel, es especialmente vulnerable al cambio global y debe ser protegido de la deforestación, que avanza constantemente. Pinus halepensis, que ocupa 880.000 ha, es la especie dominante en las regiones semiáridas y áridas. Los suelos de estas regiones son generalmente frágiles y vulnerables debido a la aridez climática y su degradación ha acentuado el fenómeno de la desertificación. El objetivo de este trabajo fue comparar características fisicoquímicas y microbiológicas de suelos forestales de coníferas de las zonas semiáridas y áridas del oeste argelino. Además de la caracterización de los climas, se analizaron 16 propiedades físicas, químicas y microbiológicas en suelos recolectados de áreas forestales características de dos zonas: macizo forestal de Jebel Sid Ahmed Zeggai (provincia de Saida), situado en la zona semiárida, y macizo forestal de Jebel Antar (provincia de Naama), en la zona árida. Los resultados mostraron calidades de suelo muy diferentes entre las dos zonas: el contenido de humedad, la capacidad de retención de agua, la permeabilidad, la porosidad y el contenido de carbono orgánico, el nitrógeno total y la materia orgánica son más altos en la zona semiárida en comparación con la zona árida, que se caracteriza por la gran presencia de caliza. La biomasa y la respiración basal microbiana fueron mayores en la zona semiárida. Se discuten los resultados con respecto a la vulnerabilidad de los suelos, al clima respectivo de cada zonas y prácticas agro-silvícolas potencialmente involucradas en la degradación de estos suelos.

Palabras clave: calidad del suelo, pino carrasco, degradación, sequía, vulnerabilidad.

\section{INTRODUCTION}

The Mediterranean region is one of the 34 hot spots of biodiversity identified at global level. This richness is explained by the diversity of geological and edaphic contexts, by strong heterogeneity of the climatological conditions at meso-and micro-scale, and by the seniority and importance of agro-pastoral practices. This region is subject to strong environmental pressures of different natures: climatic stresses (intense and prolonged droughts), 
poor soil conditions (thin, sandy, poor and xeric soils) and anthropogenic perturbations more and more intensely linked to the development of human populations. All the typical pressures of the Mediterranean regions are exacerbated in the semi-arid and arid north African environments. In Algeria, the degradation of natural resources remains a topical problem associated with climate change, deforestation and intensive pastoralism, soil erosion and the recurrence of fires. The Mediterranean forest is characterized by a typical flora, which gives it a geographical delimitation, according to the foresters, in relation to its bioclimate with its two main components: precipitation and drought. It covered about 85 million hectares in 2010 or $2 \%$ of the world's forest surface. The Algerian forest belongs to this ensemble; it presents an element of ecological, climatic and socio-economic equilibrium (FAO 2013). The current situation of the Algerian forests is one of the most critical in the Mediterranean region and their sustainable management needs to be informed by an assessment of the physico-chemical and biological quality of soils. The Mediterranean climate is, by its typicality (i.e. hot and dry summer existence) expressing itself on a wide spatial scale, and by its alti-latitudinal variability, the major structuring factor of intercontinental unity and landscape-wide diversity of mediterranean forest ecosystems. The consequences of this climate and its variants on the composition, functioning and evolution of the natural environment are today relatively well known thanks to the numerous works carried out since the middle of the twentieth century (Quézel and Médail 2003). Thus, a large part of the Algerian territory is classified into two zones differentiated by their meteorological precipitation regime: the semi-arid zone (annual precipitations between $300 \mathrm{~mm}$ and $600 \mathrm{~mm}$ ) and the arid zone (annual precipitations $<300 \mathrm{~mm}$ ). According to Halitim (2011), the arid zone covers almost $95 \%$ of the national territory, of which $89.5 \%$ includes the hyper arid (Saharan) domain. In the Mediterranean context and in response to disturbances, climatic stresses and anthropogenic uses, most Mediterranean forests represent unbalanced systems, generally well adapted in space and time to various Soil constraints, and thus to changes in the dynamics or structure and architecture of the stands they can generate (Barbero and Quézel 1989). Increased fire frequency can severely degrade soil quality (Borsali 2013). The degradation of a soil corresponds to the loss or reduction of its functions and is mainly due to a decrease in its productive capacities and its environmental regulation capacity, thus contributing to the biological cycle deregulation (Soubeyroux et al. 2012). The deregulation of these cycles can alter the nutrient cycles resulting in ecosystem degradation and indirectly an impact on human well-being. Thus, the acceleration of erosion by runoff is a direct consequence of the loss of vegetation cover as an effect of fire or clearing, resulting in serious consequences for fertility and soil quality. This generates rapid degradation of the forest ecosystem with sometimes lasting consequences for ani- mal and plant biodiversity (UNCCD 2011). The stressful climatic conditions of the Algerian semi-arid and arid regions, and in particular the intense and durable drought, directly affect the physico-chemical characteristics of the soils and the microflora in diversity and functionality. If certain tolerance thresholds are exceeded then these too recurrent events can disturb the pre-existing equilibria and alter the ecological stability of the soils (Guenon 2010). The resilience and resilience capacities of microbial communities in arid and semi-arid soils in the face of climate change stresses remain unknown, and no work in Algeria describes the effects of climate and action vulnerability of these soils and in particular the state of the microbial flora in the face of the stresses of climate change. In the Mediterranean forest context and within the Algerian West region, vegetation studies have been approached in different bioclimatic scales. They have shown a transformation of the original vegetation and the disappearance of some species especially in semi-arid and arid areas. This has been observed by several scientists who link this phenomenon to climate change in these regions marked in recent years by long periods of drought; nevertheless no study shows the current state of quality of the soils of these areas and their effect on vegetation. Our hypothesis is that these changes in landscape and the regression of some plant species are not only the result of climate change but also that they are due to profound changes within the soil. Furthermore, we wanted to see if there is an effect of the aridity gradient on some soil properties, such as nutrient content and microbial activities that are normally lower in arid areas than in semi-arid areas. To understand and see if these transformations are the results of a latitudinal gradient of aridity, we have selected two zones located respectively in the semiarid and arid bioclimatic stages. Our choice is focused on these two areas because it is at this level that we see the most degradation of plants and soils and it is also the last barriers to desertification.

To achieve this work we chose soils located at the same altitude, the same exhibition and on the same limestone mother rock of two forested massifs of Aleppo pine (Pinus halepensis Mill.) representative of the semi-arid and arid areas of western Algerian.

\section{METHODS}

Presentation of the study areas. Two forest areas have been selected for our work:

- Jebel Sid Ahmed Zeggai forest massif (34 $50^{\prime}$ $12.7^{\prime \prime} \mathrm{N}, 00^{\circ} 05^{\prime} 14.2 " \mathrm{E}$ ) is located in the semiarid zone, $4.5 \mathrm{~km}$ west of Saida Province on brown limestone soils (figure 1). It has been a crown forest since 1962 with an area of 2,232 ha dominated by Aleppo pine at $90 \%$. The accompanying species are lentisk (Pistacia lentiscus L), juniper (Juniperus oxycedrus $\mathrm{L}$ ), green oak (Quercus ilex $\mathrm{L})$ and 
alfa (Stipa tenacissima (L.) Kunth). This forest is very dense $(2,000$ plants/ha) and has a significant regeneration. Aleppo pine has an average age of 50 years and an average height varying from 6 to $8 \mathrm{~m}$. According to Salamani et al. (2013), this semi-arid zone is moderately susceptible to desertification and has a low insensitive vegetation index.

- Jebel Antar forest massif $\left(33^{\circ} 32^{\prime} 24.1 ” \mathrm{~N}, 00^{\circ}\right.$ $18^{\prime} 24.9^{\prime \prime} \mathrm{W}$ ) is a reforestation of Aleppo pine located in the arid zone $30 \mathrm{~km}$ from Naama Province on brown limestone soils with crusting gypsum on a calcimagnesic rock (Bensaid 2006) (figure 1). This reforestation was carried out by the ONF (National Forest Office) on an area of 1,034 ha in 1975. Aleppo pine is used as a main species at a rate of 95 $\%$ with a density of 1600 plants/ha with accompanying species such as Cupressus sp., Pistacia antlantica Desf., white Retama raetam (Forssk.) Webb et Berth, Stipa tenacissima and Artemisia herba-alba Asso. According to the vegetation layer and desertification sensitivity maps presented in Salamani et al. (2013), this arid zone has a high sensitivity vegetation index and high sensitivity to desertification.

A monthly analysis of meteorological precipitation and temperature data collected on the nearby climatic stations of Mecheria (arid, $3 \mathrm{~km}$ from the study area; $33^{\circ} 31^{\prime} \mathrm{N}$; $00^{\circ} 17^{\prime} \mathrm{W}$ ) and Rebahia (semi- arid, $4 \mathrm{~km}$ from the study area; $34^{\circ} 52^{\prime} \mathrm{N}$; $00^{\circ} 10^{\prime} \mathrm{E}$ ) makes it possible to finely characterize the climate of the two studied areas. Ombrothermic diagrams, calculated over the period 1985 to 2015, are shown in figure 2 . The semi-arid zone has an average of $361.77 \mathrm{~mm}$ year $^{-1}$ with a seasonal diet of type WASS (winter $>$ autumn $>$ spring $>$ summer), where precipitation is more abundant in winter and autumn. The arid zone receives an average of $222.06 \mathrm{~mm}$ year ${ }^{-1}$ with a seasonal diet of type subsection ASWS (autumn $>$ spring $>$ winter $>$ summer). January is the coldest month with an average of $8.66{ }^{\circ} \mathrm{C}$ in the semi-arid and $5.66{ }^{\circ} \mathrm{C}$ in the arid, while July is the hottest month with an average of $27.26^{\circ} \mathrm{C}$ and 28.79 ${ }^{\circ} \mathrm{C}$ in semi-arid and arid zones respectively. The semi-arid zone has a dry period of almost 6 months from May to October and 38 days of jelly on average per year. The arid zone has 8 months of drought with a period of jelly that averages over 40 days (figure 2).

According to figure 2, we recorded similar temperatures between the two zones with a slight rise in temperatures observed during the summer period in the arid zone, although there is a significant difference in precipitation between the Two zones especially between October and May.

Choice of stations. In each zone (arid and semi-arid) 25 soil samples were collected from five sampling stations of $400 \mathrm{~m}^{2}$ each and at least $5 \mathrm{~km}$ distant. The fifty (50) soil samples were randomly collected during March 2016

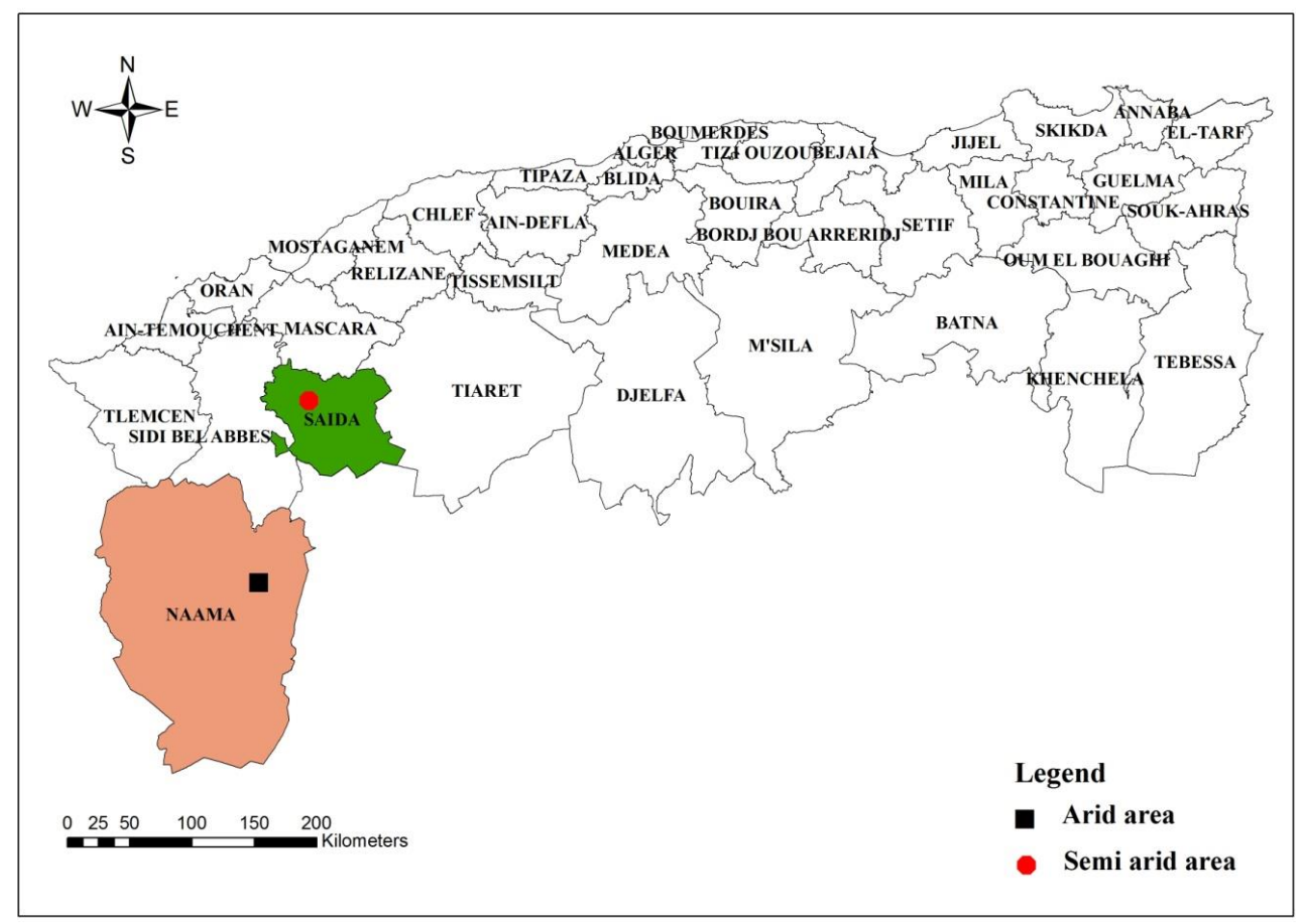

Figure 1. Geographical situations of study areas.

Ubicación geográfica de las áreas de estudio. 


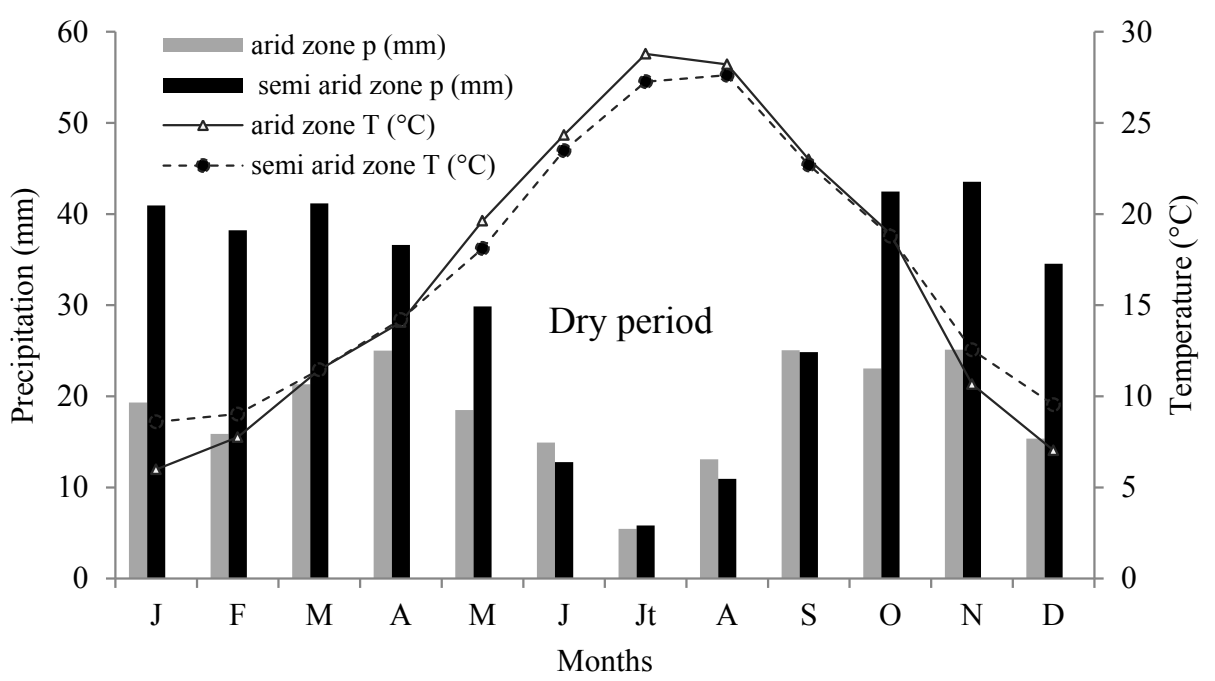

Figure 2. Ombrothermic diagram over 30 years in the semi-arid and arid zone.

Diagrama ombrotérmico de más de 30 años en la zona semiárida y árida.

after litter was eliminated at a depth of 0 to $10 \mathrm{~cm}$. All stations are located between 970 and $1280 \mathrm{~m}$ of altitude. The samples were sieved at $2 \mathrm{~mm}$, some analyses were carried out on the same day (moisture). Other physico-chemical analyses were carried out on air-dried soils for three days, or kept at $4{ }^{\circ} \mathrm{C}$; microbiological analyses still pending.

Study of properties and physical characteristics of soils. A particle size analysis of the three fractions of fine earth (sands from $2,000 \mu \mathrm{m}$ to $50 \mu \mathrm{m}$, silts from $50 \mu \mathrm{m}$ to $2 \mu \mathrm{m}$, clays $<2 \mu \mathrm{m}$ ) was carried out by sedimentation using the Robinson Pipette method (Aubert 1978). Colors are determined by the Munsell Soil Color Chart. Soil moisture was determined by subtracting the mass of a sample of dried soil $\left(105^{\circ} \mathrm{C}, 24 \mathrm{~h}\right)$ from that of this sample before drying. Apparent density was determined by the cylinder method. Five soil samples were collected from known volume cylinders $(\mathrm{h}=5 \mathrm{~cm}$ and $\mathrm{r}=3 \mathrm{~cm})$, dried and weighed. Real density was determined by the pycnometer method (Aubert 1978). The permeability of a soil is the measured water height per centimeter that infiltrates per unit of time in the soil. Water retention capacity was measured by weighing a water saturated sample after decanting for $24 \mathrm{~h}$ at $4{ }^{\circ} \mathrm{C}$.

Study of the chemical properties of soils. $\mathrm{pH}$ was measured in a soil and distilled water suspension $(1: 2.5)$. The measurement was performed after $2 \mathrm{~h}$ of stabilization at room temperature using a Metrom $\mathrm{pH}$ Meter (Herisau, Switzerland). Calcium carbonate was determined using a Bernard Calcimeter (Aubert 1978). Total nitrogen levels were determined by the Kjeldhal method (Aubert 1978). The nitrogen of organic compounds is converted into ammonium nitrogen by sulfuric acid $\left(18 \mathrm{~mol} \mathrm{~L}^{-1}\right)$ brought to a boil. Afterwards, ammonia is distilled in a solution of boric acid. It is titled with a sulfuric acid solution at $0.01 \mathrm{~mol} \mathrm{~L}^{-1}$. Organic carbon (CO) is determined by the Anne method (Aubert 1978). Organic matter content was measured by mass loss of a dry sample during calcination at $550{ }^{\circ} \mathrm{C}$ for 16 hours. Silicon ( $\mathrm{Si}$ ), aluminum (Al), iron $(\mathrm{Fe})$, calcium $(\mathrm{Ca})$, magnesium $(\mathrm{Mg})$ and potassium $(\mathrm{K})$ element contents were determined by X-ray fluorescence in oxidized form on a solid solution sample called lozenge. This procedure is related to the practical instrumental method of basic soil analysis by X-ray fluorescence spectrophotometry.

Analysis of basal respiration and microbial biomass. Basal respiration (C-CO $\mathrm{CO}_{2} \mathrm{~g}^{-1}$ dry soil) was measured according to the protocol described by Anderson and Domsch (1978) using a chromatograph equipped with a TCD detector and a filled column (Porapack) in which helium circulates at a flux of $60 \mathrm{~mL} \mathrm{~h}^{-1}$, which measures carbon dioxide $\left(\mathrm{CO}_{2}\right)$ concentrations after incubation to obtain the amount of carbon dioxide $\left(\mathrm{CO}_{2}\right)$ produced by the heterotrophic microorganisms contained in the sample to assess the physiological state of soil microbial communities.

Microbial biomass was estimated by the glucose-induced respiration method (Anderson and Domsch 1978). The carbon dioxide $\left(\mathrm{CO}_{2}\right)$ concentration of the vials was analyzed by gas chromatography and corrected in the same way as previously described for basal respiration after incubation with a mixture of talc and glucose. Induced respiration rates were converted to microbial biomass value.

Data analyses. The student t-test was used to compare the results of the physico-chemical and microbiological properties of soils between the semi-arid and arid zones by R-3.5.2 software statistical. 


\section{RESULTS}

Physical properties of soils in arid and semi-arid areas. Arid and semi-arid zones exhibit significantly different physical properties except for apparent density (table 1). On the basis of average particle size composition, the soils studied in the semi-arid zone have a silt-sandy texture while the soils of the arid zone have a sandy-clay texture. Soil moisture at the time of sampling, retention capacity, permeability and porosity were all significantly higher in the soil of the semi-arid forest mass if compared with the soils of the arid forest. The soils of the semi-arid zone have a color that varies from reddish brown, reddish brown to brown and red. The soils of the arid zone have a generally orange color for all stations.

Chemical properties of soils in the arid and semi-arid zone. Statistical tests show that the chemical properties of soils in arid and semi-arid areas, except for magnesium oxide $(\mathrm{MgO})$ and aluminium oxide $\left(\mathrm{Al}_{2} \mathrm{O}_{3}\right)$, are significantly different (table 2). Total limestone and calcium oxide levels are higher in soils of the arid zone, while levels of carbon $(\mathrm{C})$ and nitrogen $(\mathrm{N})$, organic matter, potassium oxide, iron oxide and silicon dioxide are higher in the soils of the semi-arid zone. The $\mathrm{C} / \mathrm{N}$ ratio calculated for soils of the arid zone (31.60) is twice as high as that obtained in soils of the semi-arid zone (19.25). Soil water $\mathrm{pH}$ is alkaline regardless of area, although it is higher in the arid zone.

Biomass and microbial basal respiration of soils. For microbiological properties, microbial biomass was higher in soils from the semi-arid zone (Cmic: $35.68 \mu \mathrm{g} \mathrm{g}^{-1}$ ) than in those from the arid zone (Cmic: $19.93 \mu \mathrm{g} \mathrm{g}^{-1}$ ) with a moderately significant difference $(P<0.01)$. Basal respiration remains correlated with microbial biomass; it has

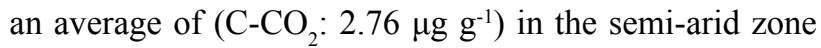
and an average of $\left(\mathrm{C}^{-} \mathrm{CO}_{2}: 1.72 \mu \mathrm{g} \mathrm{g}^{-1}\right)$ in the arid zone. The comparison of average basal respiration between the two zones shows a significant difference $(P<0.05)$. Basal respiration remains very low in both areas compared to microbial biomass.

\section{DISCUSSION}

The diversity and distribution of vegetation in the arid and semi-arid Algerian areas depend on the precipitation regime, the soil condition and the geomorphology of the land. Algeria is known for the diversity of these soils and its plant and wildlife resources. In Algeria, the forests of arid and semi-arid lands play a leading role in the conservation of biodiversity and soils. Given the increasingly uncertain climatic conditions and the associated effects in all arid zones, it is essential to develop new approaches to soil management and safeguards because if they are well managed, they will contribute to reduce the impact of climate change. In fact, when comparing the precipitation of the old period (1913-1930) with the new period (1985-2015), it is noted that there is a regression of the average annual precipitation in the semi-arid zone from 430 to $361 \mathrm{~mm}$ year $^{-1}$ and in the arid zone from 293 to $222 \mathrm{~mm}_{\text {year }}{ }^{-1}$. An increase in the annual temperature averages, in the semiarid zone of $0.25^{\circ} \mathrm{C}$ and $0.9^{\circ} \mathrm{C}$ in the arid zone compared

Table 1. Physical properties of forest soils in the arid zone and the semi-arid zone.

Propiedades físicas de los suelos forestales en las zonas árida y semiárida.

\begin{tabular}{|c|c|c|c|}
\hline Physical variables & Calculated $t$ value and significance & Semi-arid areas & Arid areas \\
\hline Texture & - & Sandy-loam & Sandy-clay \\
\hline \multirow[t]{3}{*}{ Granulometric composition } & - & Sand $60.62 \%$ & Sand $68.23 \%$ \\
\hline & - & Silt $24.20 \%$ & Silt $5.11 \%$ \\
\hline & - & Clay $15.18 \%$ & Clay $26.66 \%$ \\
\hline \multirow[t]{2}{*}{ Color } & - & Reddish brown & Orange \\
\hline & - & Brown and Red & \\
\hline Moisture (\%) & $\mathrm{t}=9.94 \quad P<0.001 * * *$ & $18.56 \pm 6.57^{\mathrm{b}}$ & $5.23 \pm 1.25^{\mathrm{a}}$ \\
\hline Water retention capacity (\%) & $\mathrm{t}=11.14 \quad P<0.001 * * *$ & $71.33 \pm 7.83^{b}$ & $51.34 \pm 4.37^{\mathrm{a}}$ \\
\hline Permeability $\left(\mathrm{cm} \mathrm{h}^{-1}\right)$ & $\mathrm{t}=23.96 P<0.001 * * *$ & $47.79 \pm 3.00^{\mathrm{b}}$ & $28.20 \pm 2.77^{\mathrm{a}}$ \\
\hline Porosity (\%) & $\mathrm{t}=34.50 \quad P<0.001^{* * *}$ & $77.56 \pm 5.92^{\mathrm{b}}$ & $28.17 \pm 4.01^{\mathrm{a}}$ \\
\hline Apparent density(Da) & $\mathrm{t}=0.83 \quad P>0.05 \mathrm{~ns}$ & $1.09 \pm 0.17^{\mathrm{a}}$ & $1.06 \pm 0.13^{\mathrm{a}}$ \\
\hline Real density (Dr) & $\mathrm{t}=16.74 \quad P<0.001 * * *$ & $5.12 \pm 1.06^{\mathrm{b}}$ & $1.48 \pm 0.20^{\mathrm{a}}$ \\
\hline
\end{tabular}

SE:Averages \pm standard deviations. The t-value of the Student's test is presented with its significance threshold $(*: P<0.05, * *: P<0.01, * * *: P<$ 0.001 , ns: not significant). Different letters in each column indicate significant differences (Fisher LSD, $P<0.05$ ). 
Table 2. Chemical properties of forest soils in the arid zone and the semi-arid zone.

Propiedades químicas de los suelos forestales en las zonas árida y semiárida.

\begin{tabular}{|c|c|c|c|c|}
\hline Chemical variables & Calculated t valu & and significance $P$ & Semi-arid areas & Arid areas \\
\hline Carbone (C) $\left(\mathrm{g} \mathrm{kg}^{-1}\right)$ & $\mathrm{t}=4.15$ & $P<0.001^{* * *}$ & $6.24 \pm 1.26^{\mathrm{b}}$ & $4.74 \pm 2.03^{\mathrm{a}}$ \\
\hline Nitrogen $(\mathrm{N})\left(\mathrm{g} \mathrm{kg}^{-1}\right)$ & $\mathrm{t}=3.03$ & $P<0.01 * *$ & $0.32 \pm 0.085^{\mathrm{b}}$ & $0.15 \pm 0.04^{\mathrm{a}}$ \\
\hline $\mathrm{C} / \mathrm{N}$ & $t=8.67$ & $P<0.001^{* * *}$ & $19.25 \pm 3,64^{\mathrm{a}}$ & $31.60 \pm 11.41^{\mathrm{b}}$ \\
\hline Organic matter, $\mathrm{MO}(\%)$ & $\mathrm{t}=5.90$ & $P<0.001^{* * *}$ & $7.84 \pm 1,43^{\mathrm{b}}$ & $4.67 \pm 1.13^{\mathrm{a}}$ \\
\hline $\mathrm{pH}$ water & $\mathrm{t}=4.54$ & $P<0.001^{* * *}$ & $8.20 \pm 0,55^{\mathrm{a}}$ & $8.72 \pm 0.17^{\mathrm{b}}$ \\
\hline $\mathrm{pH} \mathrm{KCl}$ & $\mathrm{t}=3.73$ & $P<0.001^{* * *}$ & $7.28 \pm 0.442^{\mathrm{a}}$ & $7.62 \pm 0.09^{\mathrm{b}}$ \\
\hline Conductivity (mS) & $\mathrm{t}=4.42$ & $P<0.001^{* * *}$ & $0.47 \pm 0.07^{\mathrm{a}}$ & $0.73 \pm 0.27^{\mathrm{b}}$ \\
\hline Total limestone (\%) & $\mathrm{t}=8.33$ & $P<0.001^{* * *}$ & $27.03 \pm 10.25^{\mathrm{a}}$ & $48.84 \pm 8.12^{\mathrm{b}}$ \\
\hline Potassium oxide $\left(\mathrm{K}_{2} \mathrm{O}\right)(\%)$ & $t=17.82$ & $P<0.001^{* * *}$ & $1.84 \pm 0.033^{\mathrm{b}}$ & $1.70 \pm 0.020^{\mathrm{a}}$ \\
\hline Iron oxide $\left(\mathrm{Fe}_{2} \mathrm{O}_{3}\right)(\%)$ & $\mathrm{t}=2.11$ & $P<0.05^{*}$ & $7.17 \pm 2.28^{\mathrm{b}}$ & $6.18 \pm 0.55^{\mathrm{a}}$ \\
\hline Silicon dioxide $\left(\mathrm{SiO}_{2}\right)(\%)$ & $\mathrm{t}=11.88$ & $P<0.001^{* * *}$ & $61.03 \pm 7.85^{\mathrm{b}}$ & $41.70 \pm 2.12^{\mathrm{a}}$ \\
\hline Magnesium oxide (MgO) (\%) & $\mathrm{t}=1.41$ & $P>0.05 \mathrm{~ns}$ & $0.51 \pm 0.13$ & $0.56 \pm 0.14$ \\
\hline Aluminium oxide $\left(\mathrm{Al}_{2} \mathrm{O}_{3}\right)(\%)$ & $\mathrm{t}=0.52$ & $P>0.05 \mathrm{~ns}$ & $10.59 \pm 1.65$ & $10.41 \pm 0.58$ \\
\hline Calcium oxide $(\mathrm{CaO})(\%)$ & $t=28.86$ & $P<0.001^{* * *}$ & $9.87 \pm 1.97^{\mathrm{a}}$ & $21.79 \pm 0.60^{\mathrm{b}}$ \\
\hline
\end{tabular}

Averages \pm standard deviations. The t-value of the Student's test is presented with its significance threshold $(*: P<0.05, * *: P<0.01, * * *: P<0.001$, ns: not significant). Different letters in each column indicate significant differences (Fisher LSD, $P<0.05$ ).

with the period 1913-1938, is also noted (Nedjraoui 2001, Bensaid 2006).

In the Mediterranean basin, weather models forecast an increase in summer droughts and increased temperatures. This overall trend would be accompanied by a larger frequency of extreme events such as torrential rain and drought (Soubeyroux et al. 2012). These extreme events, their intensity (duration, frequency) and the suddenness with which they arrive are likely to directly affect the soils causing their degradation and consequently the desertification of these areas.

Effects of aridity gradient on the physical quality of soil. The knowledge of the texture allows indicating the physical quality of a soil especially on the water regime. According to the triangle of textures, results showed us that our semi-arid zone is characterized by sandy-loam texture and the arid zone has sandy-clay texture. According to our results, the soil color of the semi-arid zone (reddish brown, brown and red) is an indicator of limestone-rich calcimagnesic bedrock with iron in the superficial horizons (Bensaid 2006). The soil color of the arid zone forest (orange) is the result of the large presence of limestone and iron. In soils of the arid region, we measured very low moisture levels with an average of (5.23\%), compared to soils in the semi-arid region (18.56\%), depending on climatic conditions in the first place (temperature and precipitation) as well as on the density of vegetation cover that differs between the two zones.
Our semi-arid zone, represented by the forest of djebel Sid Ahmed Zeggai, has a significant vegetation cover; sometimes density exceeds $50 \%$ (General Directorate of Forestry 2015). In addition, quantity and quality of litter and humus, very present in this forest, play the role of a sponge. They keep water and protect the soil from evaporation. Borsali (2013) shows in his research on semi-arid forests that soil moisture depends mainly on climatic conditions (temperature and precipitation). The low moisture in our arid zone can be explained not only by the extreme climatic conditions and the sandy texture of soil, but also by the low density of the forest which does not exceed (20\%) (General Directorate of Forestry 2015) and the absence of the herbaceous mat that accelerates the evaporation of water contained in the soil at limited depth in the soils of this area.

The low retention capacity $(51.34 \%)$ in the arid zone contrasted to the semi-arid zone $(71.33 \%)$ can be explained first by low clay content and high sand content especially in the arid zone, which has important percentage of sand $(68.23 \%)$; it varies according to texture, structure and maximum rooting depth of soils (Bourennane et al. 2008). Retention capacity is low in the soils of the arid zone following the regression of the vegetation which results in a decrease of the organic matter that holds water. This retention capacity is less important in arid soils than in semi-arid soils due to the effect of the aridity of the climate and the action of erosion (water and wind) very important in this area (Salamani et al. 2013) and under the 
effect of the desertification that increases the percentage of sand in the arid zone and changes soil texture (Fayos 1997). According to Duchaufour (1984), porosity (P) is closely related to two characteristic values: Real density $(\mathrm{Dr})$ and apparent density $(\mathrm{Da})$. Porosity and permeability in the arid zone are low $\left(28.14 \% ; 28.20 \mathrm{~cm} \mathrm{~h}^{-1}\right)$ compared to the semi-arid zone $\left(77.56 \% ; 47.79 \mathrm{~cm} \mathrm{~h}^{-1}\right)$ and this depends primarily on texture (presence of clay) and the effects of soil compaction which reduces the circulation of air and water depending on real density (Dr) and apparent density (Da). Arid soils are generally compacted soils (Aubert 1978), this compaction affects the physical quality of the soil, reduces porosity, resulting in poor aeration of the soil. The permeability of a soil is always correlated with porosity. This is according to the nature of infiltration: both via a slow component linked to very fine porosity and a rapid component via the well organized fracture network (Pinault 2006).

Effects of area on chemical properties. Our results show a low level of organic carbon $\left(4.74 \mathrm{~g} \mathrm{~kg}^{-1}\right)$ and organic matter $(4.67 \%)$ in the arid zone contrasted to the semiarid zone (carbon: $6.24 \mathrm{~g} \mathrm{~kg}^{-1}$; organic matter: $7.84 \%$ ), this is certainly due to the low density of Vegetation and degraded litter in the arid zone. In fact, Bensaid (2006) in a work on desertification in this zone shows that the degradation of the main forest litter source of carbon in the soil is related to climatic and edaphic factors (humidity, $\mathrm{pH}$, texture and microbial biomass). Furthermore, the existence of frequent winds in arid zones can carry litter from one place to another. In soils of the arid zone, organic matter is still low and the time of residence of organic carbon in these soils is highly variable depending on the origin of the soil, climate and land use (Girard et al. 2005). The organic stock in the soil varies considerably according to the speed of its renewal (turnover): It is low if the renewal is rapid (strong biological activity), the speed of this process depends on factors such as temperature and precipitation, the hydrographic equilibrium of the soil and the composition of the organic matter (European Union 2011). The significant difference (Student t-test) of nitrogen between our arid zone $\left(0.15 \mathrm{~g} \mathrm{~kg}^{-1}\right)$ and the semi-arid zone $\left(0.32 \mathrm{~g} \mathrm{~kg}^{-1}\right)$ is probably related to the rate of mineralization and the nature of plant species that differs between the two forest masses. According to (Soudi et al. 2003) the cycles of nitrogen and organic matter are of considerable importance in the arid and semi-arid Mediterranean context and the availability of nitrogen for plants is closely related to the quantity and quality of soil organic matter.

The high $\mathrm{C} / \mathrm{N}$ ratio in our arid zone (31.60) testifies to a low nitrogen releasing humus. This small amount of nitrogen in our arid zone does not allow good carbon decomposition: there is competition between the absorption by plants and the reorganization of the organic matter by the microorganisms of the soil, it is the phenomenon of "nitrogen hunger", so nitrogen is subsequently taken from the soil reserves, the mineralization is slow and only a small amount of mineral nitrogen is returned to the soil $(\mathrm{C} / \mathrm{N}>30)$. While in the semi-arid zone there is a nitrogen production, the rate of decomposition increases to allow good decomposition of the carbonaceous material $(\mathrm{C} / \mathrm{N}<$ 25) (the ammonium and nitrate libration overtakes the reorganization and feeding nitrogen from trees becomes possible) (Baise 2000). Some authors show that the $\mathrm{C} / \mathrm{N}$ ratio is higher in conifer stands compared with hardwood stands (Gunderson et al. 2009), and others confirmed that the C/N ratio is for dry-zone soils (Righi and Wilbert 1984).

The $\mathrm{pH}$ of the soils studied is generally alkaline, the degradation of soils by alkalinity appears as a backdrop to all forest facilities in arid or semi-arid zones. These are the most frequent types of degradation especially in our arid zone and often linked to desertification. A pH between 8 and 9 is retained, usually as a limit to the degradation of the structure (Aubert 1978). According to Aubert's salinity scale (1978), the soils of our semi-arid zone are considered to be unsalted soils and the soils of the arid zone are poorly salted; drought and low vegetation density increase salinization of soils, some salts present in the natural state in soil are absorbed as nutrients by plants (Wiebe et al. 2007). The high level of limestone and calcium in the arid zone is due to the presence of limestone crust in these soils. They depend on the depth of the mother rock; in our arid zone the depth of the soil is limited (Bensaid 2006). According to the IPCC (2007), the types of calcareous soils in Algeria are soils with deep limestone accumulation in semi-arid and arid bioclimates. The evolution of limestone is important in the genesis of soils in these regions. Drouet (2010) showed that the levels of calcium carbonate $\left(\mathrm{CaCO}_{3}\right)$ in carbonated soils were highly variable: from a few percentage to more than $70 \%$. The most abundant carbonate was calcite. The presence of carbonates strongly influences soil reaction, with carbonate soils distinguished by a $\mathrm{pH}$ that is still higher than 7 (Drouet 2010), this explains higher $\mathrm{pH}$ in arid soils than that of the semi-arid. Silicon is the most important mineral element in both zones $(41 \%$; $61 \%)$. Indeed some authors show that this element can frequently represent more than $50 \%$ of the mineral fraction and up to $90 \%$ or more of the silty and sandy fractions in some soils (Halilat et al, 2000).

Microbiological characteristics of soils as a function of a latitudinal gradient. Based on the statistical results, basal respiration is correlated with microbial biomass. Depending on their activity in the soil, the factors of variation in microbial biomass are temperature, moisture, the energy state of the soil (the reserves in MO, especially the easily degradable MO), physical environment (structure and porosity) and chemistry (CEC, $\mathrm{pH}$, calcium). The microbial biomass content is related to the soil type. The inactivity of micro-organisms would result in a halt in the natural supply of soils in nitrogen and a blockade of the turnover of carbon and nitrogen; thus resulting in the accumula- 
tion of these elements in organic form, unusable by plants (Dommergues et al. 2009). Our results showed that in the arid zone, the rate of basal respiration and microbial biomass are lower than in the semi-arid zone. This is due certainly to the effect of high temperatures and long periods of drought with a lack of precipitation that dominate in the arid zone. This may result in the dormancy of certain bacterial groups to withstand these extreme conditions. Karabi et al. (2015) have shown that in arid zones characterized by very restrictive edapho-climatic conditions, the survival of microorganisms in the soil is very difficult. Microbial growth may be limited by the availability of nutrients necessary for its development (Hart and Stark 1997). It is much more difficult to establish a simple relationship between soil moisture content and micro-organism activity, except for very dry or very humid ecosystems where the activity of micro-organisms is limited by soil moisture (Wardle 1998). Most authors agree that temperature and humidity are the factors that most effectively control the kinetics of organic matter mineralization by microorganisms (Borsali 2013). Some works have shown that microbial stability (i.e. resistance and resilience) is facilitated by certain abiotic factors such as nutrient availability, $\mathrm{pH}$ or the amount of carbon and its availability (Wardle 1998).

Today WMO (world meteorological organization, 2005) states that soil degradation will remain a major concern for the international community in the $21^{\text {st }}$ century, mainly in arid and semi-arid areas. This degradation will decrease fertility by: i) soil erosion caused by wind and/or water, ii) deterioration of the physical, chemical and biological or economic properties of soils, and iii) the long-term disappearance of natural vegetation.

\section{CONCLUSIONS}

The results of this study showed that the limiting factor in these soils especially in the arid zone is water, the intense drying of these soils could decrease the physicochemical quality and slow down the microbial activity of these very fragile soils.

Our results also showed that soil degradation in the arid zone is more advanced than in the semi-arid zone marked by an imbalance in soils that affects retention capacity, permeability and porosity; three key factors for soils. The organic matter and nitrogen required for mineralization have very low levels in the arid and low zone in the semiarid zone in relation to standards, reflecting and alerting the current state of the quality of these soils that tend to irreversible degradation if nothing is done for restoration. This results in a reduction of the vegetation cover observed in the field, and the decrease in the number of native plant species. This situation will cause, over time, the desertification of the arid and semi-arid zones which are the last barriers of the Sahara. Analyses of microbial biomass and basal respiration have shown that arid zones are characterized by highly constraining edapho-climatic conditions to the survival of soil microorganisms and that microbial activity is low in arid and medium forests in semi-arid areas. What is happening in the arid zone today reflects the state of the soils in a few decades in semi-arid and humid areas, seen also in the southern shore of Europe due to climate change and the increasingly intense anthropogenic action that disturbs the ecological balance of the soils of these sensitive and vulnerable areas, resulting in the extinction of plants and animals and the disappearance of a large part of the forest.

\section{ACKNOWLEDGEMENTS}

We would like to thank the team Vulnerability and Conservation Ecology, Mediterranean Institute of marine and terrestrial Biodiversity and Ecology (IMBE), AixMarseille University, France for chemical and biological soil analyses. This work is part of a doctoral research work on the impact of aridity on soils and litters in the Aleppo pine forests in western Algeria.

\section{REFERENCE}

Anderson JPE, KH Domsch, 1978. A physiological method for the quantitative measurement of microbial biomass in soils. Soil Biology and Biochemistry 10: 215-221. DOI: 10.1016/0038-0717(78)90099-8

Aubert G. 1978. Méthodes d'analyse des sols. Marseille, France. Edition C.R.D.P. 360 p.

Baise D. 2000. Guide to analyzes in pedology. 2nd ed. Paris, France. INRA. 257 p.

Barbero M, P Quézel. 1989. Structures, forest architectures with sclerophylls and fire prevention. Ecological Bulletins 20(1): 7-14.

Bensaid A. 2006. SIG et télédétection pour l'étude de l'ensablementdans une zone aride : le cas de la Wilaya de Naâma (Algérie). Doctoral thesis of Geography. Grenoble, France. University Joseph-Fourier. 319 p. https://tel.archives-ouvertes.fr/tel-00169433/document

Borsali A H. 2013. Contribution à l'évaluation de l'impact des incendies sur les écosystèmes forestiers : cas de la Forêt de Fénouane, Commune d'Ain El Hadjer, Wilaya de Saida (Algérie). Doctoral thesis. Marselle, France. Aix-Marseille University. 237 p. http://www.theses.fr/2013AIXM4362

Bourennane Schnebelen N, JL Fort. 2008. Connaître les sols pour préserver la ressource en eauKnow the soils to preserve the water resource. Guide d'application à l'échelle d'un territoire. Orléans, France. Gis Sol, Projects Group IGCS, INRA. 84 p. http://www.gissol.fr/rapports/Guide-BV.pdf

DGF (General Directorate of Frorestry, DZ). 2015. Annual report on the state of vegetation cover in Algeria (Saida and Naama). Available in http://www.dgf.org.dz/fr/structure/ conservation-forets

Drouet T. 2010. Pédologie. BING-F-302 Edition. Lagev. 140 p. http://www.geologues-prospecteurs.fr/cours/pedologie/pedologie-1.pdf

Duchaufour P. 1984. Abrégé de pédologie. Paris, France. Masson. $220 \mathrm{p}$.

Dommergues Y, E Duhoux, HG Diem. 1999. Nitrogen fixing 
trees: fundamental characteristics and role in the management of Mediterranean and tropical ecosystems, with particular reference to subhumid and arid zones. Montpellier, France. Spaces 34. 512 p. http://agritrop.cirad.fr/315506/

EU (European Union). 2011. Les sols: la face cachée du cycle climatique. DG Environment, European Commission. 24 p. http://ec.europa.eu/environment/archives/soil/pdf/soil and climate fr.pdf

FAO (Food and Agriculture Organization, IT). 2013. Etat des forêts méditerranéennes 2013. 197 p. http://www.fao.org/ docrep/017/i3226f/i3226f.pdf

Fayos CB. 1997. The roles of texture and structure in the water retention capacity of burnt Mediterranean soils with varying rainfall. Catena 31(3): 219-236. DOI https://doi. org/10.1016/S0341-8162(97)00041-6

Guénon R. 2010. Vulnérabilité des sols méditerranéens aux incendies récurrents et restauration de leurs qualités chimiques et microbiologiques par des apports de composts. Doctoral thesis. Aix-Marseille, France. University Paul Cézanne. 248 p. https://tel.archives-ouvertes.fr/tel-00555463/ document

Girard MC, C Walter, JC Remy, J Berthelin, JL Morel. 2005. Sols et environnement - Cours, exercices et etudes de cas. 2nd ed. Paris, France. Dunod Editions. 816 p.

Gunderson P, L Sevel, JR Christiansen, LVesterdal, K Hansen, A Bastrup-Birk. 2009. Do indicators of nitrogen retention and leaching differ between coniferous and broadleaved forests in Denmark? Forest Ecology and Management 258(7):1137-1146. DOI: 10.1016/j.foreco.2009.06.007

Halilat MT, MA Dogar, M Badraoui. 2000. Effet de l'azote, du potassium et de leur interaction sur la nutrition du blé sur sol sableux du désert algérien. Revue Homme, Terre Eaux 30: $32-39$.

Halitim A. 2011. Aridoculture and sustainable development. Algerian Journal of Arid Environment 1(1): 3-9.

Hart SC, JM Stark. 1997. Nitrogen limitation of the microbial biomass in an old-growth forest soil. Ecoscience 4(1): 9198. DOI: $\underline{10.1080 / 11956860.1997 .11682382}$

IPCC (Intergovernmental Panel on Climate Change). 2007. Bilan 2007 des changements climatiques: Rapport de synthèse. Contribution of Working Groups I, II and III to the Fourth Assessment Report of the Intergovernmental Panel on Cli- mate. IPCC, Geneva, Switzerland. 103 p. https://www.ipcc. ch/site/assets/uploads/2018/02/ar4 syr fr.pdf

Karabi M, BH Aissa, S Zenkhri, A Kemassi, N Bouras. 2015. Seasonal variations affect microbiocenose arid soils in the Ouargla basin (Algerian sahara). Ciência e Técnica Vitivinicola 30(8): $176-187$.

Nedjraoui D. 2001. Profil fourrager, Algeria. 36 p. https://www. vitaminedz.com/articlesfiche/0/899.pdf

Pinault JL. 2006. La sensibilité des eaux souterraines au changement climatique. Géosciences 3: 56-61.

Quézel P, F Médail. 2003. What is meant by "Mediterranean forests?" Forêt Méditerranéenne 24(1): 11-31.

Righi D, J Wilbert. 1984. Les sols sableux podzolisés des landes de Gascogne (France). Répartition et caractères principaux. Science du Sol 4: 253-264.

Salamani M, H Kadi Hanifi, A Hirche, D Nedjraoui. 2013. Assessment of desertification sensitivity in Algeria. Ecology Journal. 68(1):71-84.

Soubeyroux JM, N Kitova, M Blanchard, JP Vidal, E Martin, P Dandin. 2012. Sécheresses des sols en France et changement climatique: Résultats et applications du projet ClimSec. La Météorologie 78: 21-30. DOI: https://doi. org/10.4267/2042/47512

Soudi B, CN Chiang, H Berdai, F Naaman. 2003. Statut du cycle de l'azote et de la matiere organique en zones semi-arides irriguees et d'agriculture pluviale. Revue Homme, Terre Eaux 127: 24-31.

UNCCD (United Nations Convention to Combat Desertification). 2011. Desertification, une synthèse visuelle. $50 \mathrm{p}$. http://catalogue.unccd.int/10_Desertification_FR.pdf

Wardle DA. 1992. A comparative assessment of factors which influence microbial biomass carbon and nitrogen levels in soil. Biological Reviews 67(3): 321-358.DOI: 10.1111/j.1469185X.1992.tb00728.x

Wiebe BH, RG Eilers, WD Eilers, JA Brierley. 2007. Application of a risk indicator for assessing trends in dryland salinization risk on the Canadian Prairies. Canadian Journal of Soil Science (Special Issue) 87: 213-224. DOI: 10.4141/ $\underline{\mathrm{S} 06-068}$

WMO (World Meteorological Organization). 2005. Le climat et la dégradation des sols. Library WMO. 34 p. https:/library. wmo.int/doc_num.php?explnum id=5097 
